ANNALES

UNIVERSITATIS MARIAE CURIE-SKŁODOWSKA

LUBLIN - POLONIA

VOL. XXXIV, 1

SECTIO J

2021

${ }^{*}$ Uniwersytet Śląski w Katowicach. Wydział Sztuki i Nauk o Edukacji

${ }^{* *}$ Uniwersytet Śląski w Katowicach. Szkoła Doktorska

ANNA SZAFRAŃSKA*, JUSTYNA PAWLAK **

ORCID: 0000-0001-9797-2591; anna.gajdzica@us.edu.pl

ORCID: 0000-0001-8738-2387; justyna.pawlak@us.edu.pl

\title{
Rodzic $w$ roli nauczyciela, czyli o organizacji procesu kształcenia $i$ wychowania z perspektywy rodziców uczacych swoje dzieci w domach
}

Parent in the Teacher's Role: On the Organization of the Educational Process from the Perspective of Parents Teaching Their Children at Home

Propozycja cytowania: Szafrańska, A., Pawlak, J. (2021). Rodzic w roli nauczyciela, czyli o organizacji procesu kształcenia i wychowania z perspektywy rodziców uczących swoje dzieci w domach. Annales Universitatis Mariae Curie-Skłodowska. Sectio J, Paedagogia-Psychologia, 34(1), 79-90. DOI: $10.17951 / \mathrm{j} .2021 .34 .1 .79-90$.

\begin{abstract}
ABSTRAKT
Coraz częściej szkoła spotyka się z krytyczną oceną oraz zwiększa się potrzeba możliwości alternatywnego kształcenia dzieci i młodzieży. Wpisuje się w to rosnącą popularność edukacji domowej, w Polsce bowiem nie ma obowiązku szkolnego, tylko jest obowiązek edukacji. Przeprowadzone badania wskazują, że rodzice decydujący się na uczenie dzieci w domach rezygnują ze szkoły przede wszystkim ze względu na jej negatywną ocenę oraz własne doświadczenia, które sprawiają, że chcą chronić dzieci przed negatywnym wpływem szkoły. W niniejszym artykule zaprezentowano analizy uzyskanych wyników badań dotyczących deklaracji rodziców na temat wymaganych kompetencji, kwalifikacji i wiedzy przydatnych $\mathrm{w}$ sytuacji podejmowania się uczenia dzieci $\mathrm{w}$ domu, a także organizacji przez respondentów procesu kształcenia w systemie edukacji domowej.
\end{abstract}

Słowa kluczowe: edukacja domowa; rodzice; organizacja procesu kształcenia i wychowania 
Zabrnęliśmy w ślepy zaułek pozornego, płytkiego masowego kształcenia do nieistniejącej przeszłości. Nie może być tak dalej. Musimy to przemyśleć. Możemy to jeszcze zmienić.

(Kwieciński, 2012, s. 408)

\section{WPROWADZENIE}

Oświata od zawsze poddawana była różnym zmianom, wynikającym z oddziaływań politycznych, społecznych i ekonomicznych czy też ze zmian technologicznych. Ich efekty są czasem bardziej zauważalne, jak w przypadku polityki oświatowej wyznaczonej przez określoną politykę państwa i to, co jest konsekwencją tego oddziaływania w wymiarze teologicznym aksjologicznym, inne zaś są bardziej subtelne. Szkoła jest przecież (niestety) miejscem realizowania określonych programów nauczania, które często przyjmowane są bezrefleksyjnie i bez świadomości czemu czy też komu służą. Wreszcie kolejną sferę wpływów stanowi kadra pedagogiczna, od której tak naprawdę zależy najwięcej, tymczasem bardzo często poczucie sprawstwa jest spychane przez nauczycieli na margines samoświadomości zawodowej.

Dodatkowym problemem rzutującym na ogólny obraz szkoły są nieudane próby wprowadzania reform oświatowych. Większość wprowadzanych w Polsce zmian edukacyjnych jest traktowana zarówno przez ekspertów, badaczy oświaty, jak i przez nauczycieli czy opinię społeczną jako nieudana (Gajdzica, 2006, 2013a; Śliwerski, 2009, 2012, 2015; Szafrańska, Seberová, Kasáčová, Babiaková, 2017). To wszystko sprawia, że coraz częściej szkoła spotyka się z krytyczną oceną oraz zwiększa się potrzeba możliwości alternatywnego kształcenia dzieci i młodzieży. Wpisuje się to w rosnącą popularność edukacji domowej, w Polsce bowiem nie ma obowiązku szkolnego, tylko jest obowiązek edukacji.

Przeprowadzone badania wskazują, że rodzice decydujący się na uczenie dzieci w domach rezygnują ze szkoły przede wszystkim ze względu na jej negatywną ocenę oraz własne doświadczenia, które sprawiają, że chcą chronić dzieci przed negatywnym wpływem szkoły (Szafrańska, Pawlak, 2020).

\section{EDUKACJA DOMOWA W POLSCE - ZAŁOŻENIA ORAZ ROZWIĄZANIA PRAWNE I ORGANIZACYJNE}

Edukacja domowa nie jest nową formą kształcenia. W Polsce w różnych okresach rodzice zmuszeni byli do edukowania dzieci w domach. Tak było np. w okresie zaborów czy wojen, gdy funkcjonowało tajne nauczanie. Po II wojnie światowej ograniczone zostały możliwości kształcenia alternatywnego, w tym edukacji domowej - została ona prawnie zalegalizowana po okresie transformacji systemowej w 1989 r. Pierwszym zapisem prawnym, szczegółowo regulującym funkcjonowanie 
edukacji domowej, był art. 16 ust. 8 ustawy z dnia 7 września 1991 r. o systemie oświaty (Dz.U. 1991, nr 95, poz. 425). Obecnie zasady edukacji domowej reguluje art. 37 ustawy z dnia 14 grudnia 2016 r. - Prawo oświatowe (Dz.U. 2017, poz. 59), który brzmi: „Na wniosek rodziców dyrektor odpowiednio publicznego lub niepublicznego przedszkola, szkoły podstawowej i szkoły ponadpodstawowej, do której dziecko zostało przyjęte, może zezwolić, w drodze decyzji, na spełnianie przez dziecko odpowiednio obowiązku, o którym mowa w art. 31 ust. 4, poza przedszkolem, oddziałem przedszkolnym w szkole podstawowej lub inną formą wychowania przedszkolnego i obowiązku szkolnego lub obowiązku nauki poza szkołą”. W ust. 4 art. 37 ustawy czytamy: „Uczeń spełniający obowiązek szkolny lub obowiązek nauki poza szkołą uzyskuje roczne oceny klasyfikacyjne na podstawie rocznych egzaminów klasyfikacyjnych z zakresu części podstawy programowej obowiązującej na danym etapie edukacyjnym, uzgodnionej na dany rok szkolny z dyrektorem szkoły. Egzaminy klasyfikacyjne są przeprowadzane przez szkołę, której dyrektor zezwolił na spełnianie obowiązku szkolnego lub obowiązku nauki poza szkołą. Uczniowi takiemu nie ustala się oceny zachowania".

Powyższe akty prawne pozwalają na stwierdzenie, że edukacja domowa jest w Polsce absolutnie legalna, bo i takie wątpliwości w tej kwestii czasem się pojawiają. Przepisy te wyznaczają także formalności, jakich należy dopełnić, by stać się nauczycielem własnego dziecka (Sawiński, 2008, s. 26-29). Podjęcie takich działań jednak nie może i nie powinno być indywidualną decyzją jednego rodzica. Choćby ze względów organizacyjnych konieczne jest dokonanie ustaleń w ramach całej rodziny (Marszałek, 2018, s. 32). Kolejny krok to wybór szkoły przyjaznej edukacji domowej. Niestety, mimo rosnącej popularności edukacji domowej nadal często wielu nauczycieli i dyrektorów nie wie, że taka forma edukacji w ogóle istnieje bądź jest ona mylona z nauczaniem indywidualnym (Kobus, 2014, s. 4850). Szkoła wspierająca edukację domową powinna zapewnić rodzicom wsparcie merytoryczne, organizować konsultacje, zajęcia i warsztaty oraz wyjazdy, obozy letnie i zimowe dla dzieci, a także umożliwić dostęp do materiałów dydaktycznych, platform do nauki języków obcych czy zjazdów i spotkań w gronie rodzin edukujących dzieci w domu (Marszałek, 2018, s. 33).

Rodzice, którzy podjęli decyzję o rozpoczęciu przez dziecko edukacji domowej, muszą uzyskać opinię z publicznej poradni psychologiczno-pedagogicznej. W poradni należy złożyć wniosek o badanie psychologiczno-pedagogiczne i wydanie opinii na temat spełniania obowiązku szkolnego poza szkołą oraz złożyć dokumenty aplikacyjne do szkoły (Marszałek, 2018, s. 33). Są to: wniosek o przyjęcie dziecka do szkoły (jeśli dziecko aplikuje do innej szkoły niż ta, do której aktualnie uczęszcza) oraz zezwolenie na spełnianie obowiązku szkolnego poza szkołą; oświadczenie rodziców o zapewnieniu dziecku warunków umożliwiających realizację podstawy programowej obowiązującej na danym etapie edukacyjnym oraz zobowiązanie rodziców do przystępowania w każdym roku szkolnym przez 
dziecko do rocznych egzaminów klasyfikacyjnych. Co istotne, rodzice, którzy decydują się na rozpoczęcie edukacji domowej, mają wsparcie w postaci np. informacji zamieszczanych na stronach internetowych szkoły przyjmującej (www1) czy na forach zrzeszających członków realizujących lub zainteresowanych taką formą kształcenia dzieci (www2; www3). W niektórych szkołach konieczne jest także przedłożenie oświadczenia o miejscu zamieszkania, gdyż reforma z $2017 \mathrm{r}$. wprowadziła rejonizację wojewódzką (Dzieciątko, 2017). Na podstawie przedłożonych dokumentów dyrektor placówki, do której zapisane jest dziecko, wydaje zgodę na edukację domową obowiązującą na danym etapie edukacyjnym. Podobnie jak uczniowie tradycyjnych form kształcenia uczeń edukowany w ramach edukacji domowej otrzymuje legitymację szkolną, a na zakończenie roku szkolnego - świadectwo. Ponadto uczniowie zdają egzamin z każdego nauczanego w danej klasie przedmiotu. $Z$ początkiem roku szkoła układa grafik obejmujący około 10 kilkudniowych terminów sesji egzaminacyjnej. Dla wielu rodziców jest to doskonała okazja do rozmów i wymiany doświadczeń. Możliwe jest także umówienie się z egzaminatorem na indywidualny termin egzaminu w trakcie trwania roku szkolnego.

\section{ZAŁOŻENIA METODOLOGICZNE BADAŃ WŁASNYCH}

Badania zostały przeprowadzone w oparciu o strategię ilościową i jakościową w jednej ze szkół podstawowych położonych na południu Polski ${ }^{1}$. Warto wspomnieć, że specyfika takiej formy edukacji do 1 września 2017 r. polegała na tym, że po znalezieniu szkoły przyjaznej edukacji domowej dzieci rekrutowały się z różnych, czasami bardzo odległych miejsc w kraju (Ustawa z dnia 7 września 1991 r. o systemie oświaty, Dz.U. 1991, nr 95, poz. 425). Do szkoły, w której prowadzone były badania zapisani byli zarówno uczniowie z województwa śląskiego czy małopolskiego, jak i z województwa podkarpackiego, wielkopolskiego czy nawet pomorskiego. Informacje o szkole otwartej na edukację w domu przekazywane były przez rodziców, którzy mieli już doświadczenia w tym zakresie. Stąd niektórzy decydowali się na przyjazd dzieci na egzaminy na południe kraju, nie bacząc na odległość. Od 1 września 2017 r. rodzice decydujący się na edukację domową mogą zapisać dziecko jedynie do szkoły zlokalizowanej na terenie województwa, w którym mieszkają. Ze względu na charakter badań uczestniczyli w nich tylko rodzice, którzy mieli przynajmniej jedno dziecko w klasach I-III. Łącznie w roku szkolnym 2017/2018 do klas I-III było w badanej szkole zapisanych 269 uczniów. Celem realizowanych badań było m.in. poznanie obrazu edukacji domowej oraz spostrzegania szkoły tradycyjnej przez rodziców, którzy zdecydowali się na to, by ich dzieci były edukowane w domu.

1 Zaprezentowane analizy są fragmentem badań zrealizowanych w ramach obronionej w lipcu 2019 r. pracy magisterskiej Justyny Pawlak pt. Obraz edukacji domowej w deklaracjach dzieci, rodziców i nauczycieli, przygotowanej pod kierunkiem dr hab. Anny Szafrańskiej, prof. UŚ. 
Ogółem zostało rozprowadzonych 100 kwestionariuszy ankiet przygotowanych w tradycyjnej formie papierowej. Ankiety zostały rozdane podczas Zlotu Rodzin Edukacji Domowej w dniu 25 maja 2018 r., który odbył się w szkole, a także podczas czerwcowych (szkolnych oraz indywidualnych) sesji egzaminacyjnych w roku szkolnym 2017/2018. Zebrano 79 kwestionariuszy, co - zgodnie ze wskaźnikami przyjętymi w naukach społecznych dotyczącymi zwrotu kwestionariuszy - jest stosunkowo dużym odsetkiem.

Ankieta była złożona $\mathrm{z}$ dwunastu pytań, w tym z jednego pytania otwartego. W niniejszym artykule omówiono tylko część uzyskanych danych. W analizach skoncentrowano się na odpowiedzi na następujące pytania: Jakie są zdaniem badanych wymagane kompetencje, kwalifikacja i wiedza w sytuacji podejmowania się uczenia dzieci w domu? W jaki sposób respondenci organizują proces kształcenia w systemie edukacji domowej?

\section{O BYCIU NAUCZYCIELEM - KWALIFIKACJE, KOMPETENCJE, WIEDZA. CO JEST POTRZEBNE, ABY UCZYĆ DZIECKO W DOMU?}

We wprowadzeniu wspomniano o rosnących wymaganiach wobec nauczycieli pod względem posiadanych przez nich kwalifikacji i kompetencji. Biorąc to pod uwagę, uznano, że istotną kwestią jest zapytanie o te aspekty rodziców, którzy weszli w role nauczycieli własnych dzieci. Rodzice mieli zaznaczyć wybraną odpowiedź, wskazując, czy dane kwalifikacje, kompetencje i wiedza są ich zdaniem niezbędne, czy warto je posiadać oraz czy są lub nie są potrzebne w sytuacji samodzielnego kształcenia dzieci w domu.

Oczywiście inna jest sytuacja nauczyciela pracującego w szkole, a inna rodzica, który podejmuje decyzję, by uczyć swoje dziecko w domu. Nauczyciel pracuje w grupie o zróżnicowanych doświadczeniach, funkcjonuje w środowisku, w którym nieustannie dochodzi do swoistej konfrontacji światopoglądowej, do ścierania się różnych poglądów i postaw, co związane jest $\mathrm{z}$ reprezentowanymi przez wychowanków różnymi światami wartości. W każdej sytuacji dydaktyczno-wychowawczej nauczyciel powinien mieć świadomość odpowiedzialności związanej z kształtowaniem postaw, budowaniem świata wartości oraz obrazu samego siebie, a także budowania otwartości na innych, reprezentujących odmienne wzory kulturowe czy normy społeczne (Gajdzica, 2013b, s. 60). Przed nauczycielami stawiany jest szereg oczekiwań, które są formułowane w sposób bezpośredni np. przez rodziców uczniów czy dyrekcję oraz w sposób pośredni (tu należy też uwzględnić presję związaną z przygotowywaniem uczniów do egzaminów). Rodzic decydujący się na to, by jego dziecko uczyło się w domu zamiast w szkole tradycyjnej, staje się jednocześnie organizatorem procesu nauczania oraz nauczycielem własnego dziecka. Rzecz jasna należy przy tym mieć na uwadze, że w przypadku każdego dziecka przebieg procesu kształcenia jest w inny sposób przygotowywany, orga- 
nizowany i realizowany. Jest to uzależnione od szeregu czynników dotyczących zarówno samego dziecka, jak i uwarunkowań zewnętrznych. Warto tu zwrócić uwagę na wiek dziecka, jego dojrzałość i samodzielność w podejmowaniu działań, wcześniejsze doświadczenia w zakresie uczenia się w domu, a także kwestie ekonomiczne (możliwość organizowania przez rodziców dodatkowych, odpłatnych zajęć) czy logistyczne. Bez wątpienia taka decyzja powinna być związana z dokładnym zaplanowaniem przez rodziców tego, w jaki sposób będzie organizowana edukacja ich dziecka i zjakimi ewentualnymi trudnościami mogą się w tym zakresie mierzyć. Istotne jest również to, że rodzice podejmujący decyzję o przejęciu odpowiedzialności za edukację własnego dziecka nie muszą posiadać wykształcenia pedagogicznego (a nawet wykształcenia wyższego) ani ukończyć żadnych kursów. Są natomiast zobowiązani „zapewnić dziecku warunki umożliwiające realizację podstawy programowej" (Zielińska, 2009, s. 485).

Zdecydowana większość badanych rodziców (aż 63 osoby) uznała, że wykształcenie pedagogiczne nie jest potrzebne do tego, by uczyć dziecko w domu. Zaledwie 13 respondentów przyznało, że warto je posiadać, a 2 ankietowanych stwierdziło, że jest ono niezbędne. Nieco inaczej zostało ocenione doświadczenie w nauczaniu. W tym przypadku 50 rodziców wskazało, że jest ono niepotrzebne, 24 respondentów przyznało, że warto je posiadać, a za niezbędne uznało je 4 badanych. Jedna osoba nie odpowiedziała na te pytania. Szczegółowe dane zamieszczono na rysunku 1.

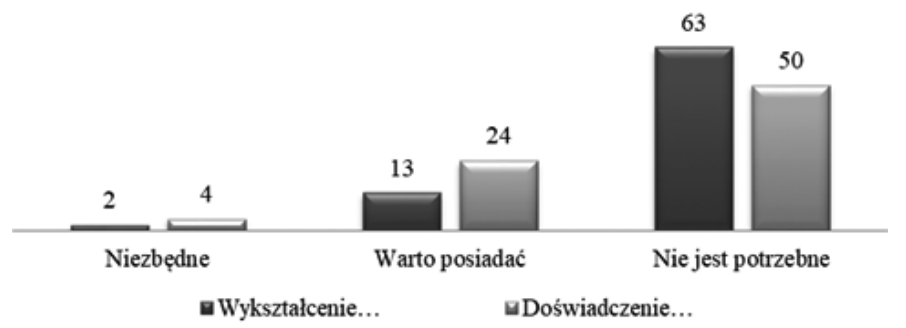

Rysunek 1. Ocena przez badanych rodziców przydatności wykształcenia i doświadczenia pedagogicznego w przypadku decyzji o edukacji domowej

Źródło: opracowanie własne.

Ze względu na przyjęty program nauczania dzieci zobowiązane są do zdawania egzaminów z języków obcych. Własne doświadczenia w tym zakresie oraz świadomość trudności związanych z przygotowywaniem dziecka do uzyskania kompetencji w zakresie języka obcego przez rodziców, którzy sami ich nie posiadają, skłoniły do zadania pytania, jak badani oceniają kwestię przydatności przez rodziców znajomości języków obcych. Żaden z respondentów nie uznał jej za niezbędną, a pozostałe odpowiedzi zostały wskazane przez zbliżoną liczebnie grupę osób, odpowiednio 40 ankietowanych uznało ją za wartą posiadania, a 38 - za niepotrzebną. 
Za istotne uznano również zapytanie rodziców o kompetencje informatyczne. Wprawdzie niemal każdy obecnie korzysta z komputera, ale czym innym jest traktowanie go jako źródła rozrywki czy wsparcia informacyjnego, a czym innym jest prowadzenie zajęć z zakresu informatyki - chodzi o wskazywaną dzisiaj jako niezbędną już na etapie edukacji wczesnoszkolnej np. naukę programowania czy kodowania (Kuźmińska-Sołśnia, 2018). Powszechnie uważa się, że kolejne pokolenia będą funkcjonowały w świecie coraz bardziej wirtualnym i zależnym od komputerów. Jednym z obszarów, który wskazuje się za najbardziej zaniedbywany w szkołach, jest właśnie nauka informatyki. Tymczasem żaden z badanych rodziców nie uznał kompetencji informatycznych za niezbędne, a tylko 7 osób stwierdziło, że warto je posiadać.

Zadaniem rodzica podejmującego wyzwanie realizowania edukacji swojego dziecka w domu jest - jak wskazano wyżej - przygotowanie go do zdania egzaminów z poszczególnych przedmiotów. Rodzice - podobnie jak nauczyciele w szkołach - nie muszą wykorzystywać określonych programów czy podręczników. Tak naprawdę punkt wyjścia stanowi podstawa programowa, w której można znaleźć wszystkie informacje na temat tego, czego na poszczególnych etapach dziecko powinno się nauczyć, jaki zakres wiedzy ma opanować. W związku z tym zapytano, jak badani oceniają przydatność znajomości podstawy programowej. Jako niezbędną uznało ją tylko 19 osób, aż 54 rodziców wskazało, że warto ją znać, a 5 ankietowanych stwierdziło, że jest to zbędne.

Jedynym obszarem, który badani rodzice niemal jednogłośnie uznali za niezbędny, jest wiedza ogólna. W tym przypadku tylko jedna osoba wyraźnie stwierdziła, że warto ją posiadać. Szczegółowe dane zamieszczono na rysunku 2.

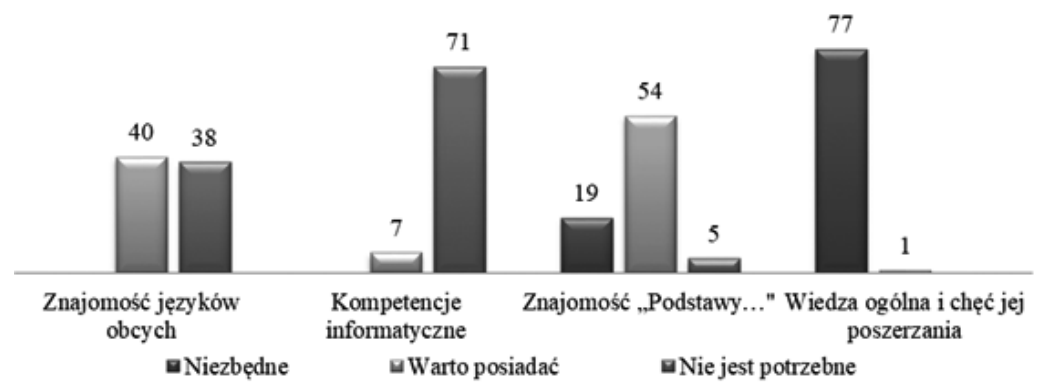

Rysunek 2. Ocena przez badanych rodziców przydatności wybranych kompetencji i wiedzy w przypadku decyzji o edukacji domowej

Źródło: opracowanie własne.

Respondenci mieli również możliwość uzupełnienia odpowiedzi o kompetencje, które przez autorki badania nie zostały wymienione, a ich zdaniem warto je posiadać, by efektywnie wspierać dziecko w edukacji domowej. Tylko 11 osób 
zdecydowało się na ten krok. Były to opisy o bardzo różnym charakterze. W zakresie wiedzy jeden z respondentów wskazał na znajomość elementów psychologii, inni zaś pisali o otwartości i ciekawości świata: „Otwartość na świat i na innych, atmosfera radości i pozytywnego nastawienia do rzeczywistości”, a także o otwartości na nowe oraz o potrzebie dobrej organizacji. Pojawiły się też odpowiedzi dotyczące zmian w samym rodzicu: „Chęć zmieniania siebie”, „Pasja do uczenia się z dziećmi”, „Własna pasja”, „Cierpliwość”. Jeden z badanych napisał o tym, że niezbędne jest „dużo miłości i chęć zmieniania siebie, praca nad sobą”. Jedna odpowiedź była szersza - rodzic wskazał na potrzebę ,zainteresowania rozwojem dziecka oraz znajomość literatury z zakresu psychorozwoju i różnych metod nauczania”, wymienił przy tym nazwiska Marii Montessori, Jagody Cieszyńskiej i Edyty Gruszczyk-Kolczyńskiej.

\section{ORGANIZACJA PROCESU KSZTAŁCENIA W EDUKACJI DOMOWEJ}

Za interesujące autorki badania uznały poznanie sposobu organizacji edukacji domowej przez badanych rodziców. Respondenci mieli możliwość zaznaczenia $\mathrm{w}$ pytaniach dotyczących organizacji procesu nauczania realizowanego w domu adekwatną do stosowanej częstotliwość: najczęściej, często, rzadko, nigdy. Rozpoczęto od pytań dotyczących tego, z kim dziecko się uczy. W niektórych wypowiedziach na forach dla rodziców podkreślana jest zmiana od uczenia przez innych do uczenia się samodzielnego przez dziecko (www4). Samodzielne uczenie się dzieci zostało wskazane jako najczęściej realizowane przez 7 rodziców, aż 49 ankietowanych napisało, że rzadko tak jest, a 23 respondentów stwierdziło, że nigdy. Potwierdzają to wyniki uzyskane w kolejnym pytaniu, w odpowiedzi na które rodzice jako najczęściej stosowaną zaznaczyli naukę pod opieką dorosłych (67 wskazań). Szczegółowe dane zamieszczono na rysunku 3.

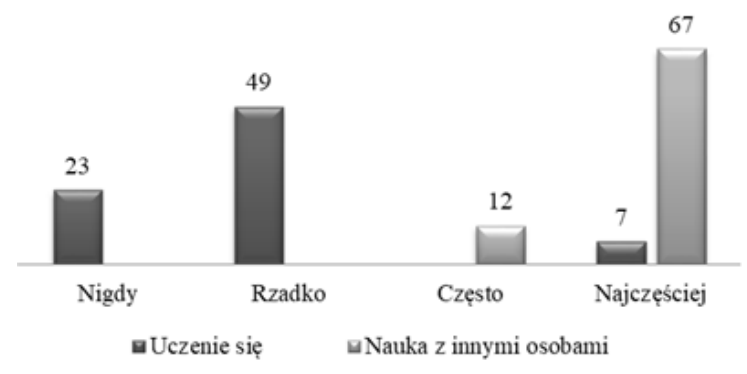

Rysunek 3. Wskazania badanych rodziców dotyczące samodzielnego lub pod opieką dorosłych uczenia się ich dzieci

Źródło: opracowanie własne. 
Istotną kwestią jest sposób organizowania zajęć dla dzieci. Rodzice wskazali, że najczęściej działają z dziećmi według wcześniej ustalonego planu (59 osób). Często postępuje tak 13 osób, a rzadko - 7. Nieco inaczej rozłożyły się odpowiedzi dotyczące systematycznej nauki. W tym przypadku 41 rodziców podkreśliło, że dziecko uczy się systematycznie, każdego dnia. Zwolennikami częstej systematyczności było 30 badanych, a odpowiedź „rzadko” zaznaczyło 8 osób. W odpowiedziach na oba pytania nie było wskazania „nigdy”. Szczegółowe dane zamieszczono na rysunku 4.

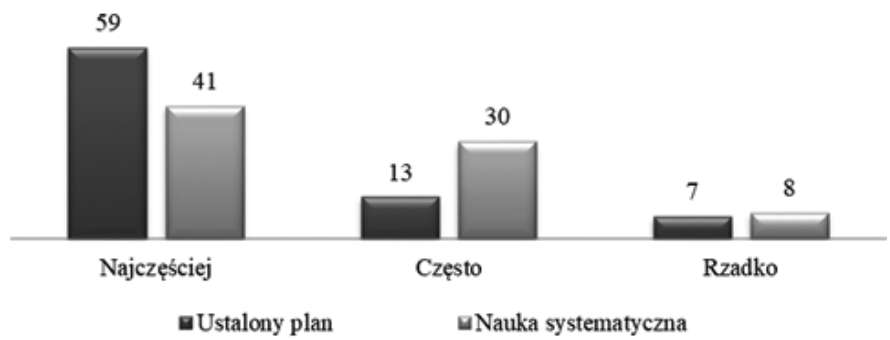

Rysunek 4. Wskazania badanych rodziców dotyczące sposobu planowania zajęć edukacyjnych dla dzieci uczących się w domu

Źródło: opracowanie własne.

W ramach przeprowadzanego badania zdecydowano się również sprawdzić, jakie jest podejście badanych rodziców do organizowania dzieciom materiału do uczenia się. Okazało się, że 6 badanych nigdy nie omawia z dziećmi dokładnie całego zakresu materiału. Aż 38 rodziców robi to rzadko, a 35 - często. Dzieci rzadko uczą się blokami tematycznymi (51 osób). Tylko 17 badanych wskazało ten sposób uczenia się jako najczęstszą formę, a 11 - jako częstą. Najwięcej respondentów (67) wskazało, że ich dziecko najczęściej uczy się zagadnień, które je interesują, a pozostałe są omawiane pobieżnie. Pozostali rodzice (12) stwierdzili, że w ich przypadku jest tak często. Szczegółowe dane zamieszczono na rysunku 5.

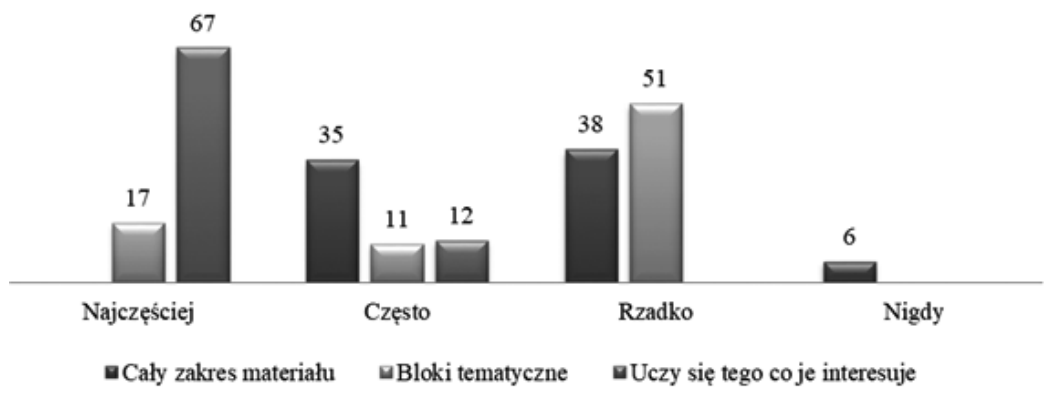

Rysunek 5. Wskazania badanych rodziców dotyczące doboru materiału do nauki Źródło: opracowanie własne. 


\section{ZAKOŃCZENIE}

Podjęcie przez rodziców trudu edukowania dzieci w domu wiąże się z różnorodnymi wyzwaniami. Na pewno powinna być to decyzja podjęta ze świadomością zmian, które będą warunkować życie zarówno rodzinne, jak i indywidualne poszczególnych członków rodziny. Największym wyzwaniem jest bez wątpienia sam sposób organizowania edukacji w domu. O ile zinstytucjonalizowana forma przebiega według określonych reguł, o tyle tu mamy do czynienia z każdorazową, indywidualną sztuką nauczania oraz z możliwością poszukiwania własnego klucza do odkrywania najbardziej efektywnych sposobów uczenia się dziecka. Ważne jest przejście do samodzielnego uczenia się dzieci (zmiana z bycia nauczanym na uczenie się). Na pewno współcześnie sytuacja rodziców w procesie edukacji domowej jest lepsza niż wcześniej, istnieje bowiem możliwość wsparcia rodzica przez szkołę, do której dziecko jest zapisane. Ponadto cenna jest aktywność własna, polegająca zarówno na uczestniczeniu w forach dla rodziców znajdujących się w podobnej sytuacji oraz na korzystaniu ze źródeł informacji dostępnych dla każdego, np. w Internecie. Na podstawie badań przeprowadzonych wśród rodziców można stwierdzić, że niepokojące jest tak silne deprecjonowanie przez nich roli wykształcenia w procesie edukacyjnym, a także kompetencji, które mogłyby im ułatwić uczenie własnego dziecka. Korzystne jest natomiast to, że większość respondentów dostrzega znaczenie systematycznej pracy i działania według ściśle ustalonego planu.

Edukacja domowa pozwala na skoncentrowanie się na tym, co dla dziecka jest najbardziej atrakcyjne i zgodne z jego zainteresowaniami - bez wątpienia jest to zaleta tego sposobu nauczania. Warto przy tym pamiętać, że takie podejście może rodzić ryzyko związane z odnalezieniem się przez dziecko na dalszych etapach kształcenia, gdy przejdzie z systemu nauczania w domu do szkoły tradycyjnej (np. na etapie szkoły średniej). Stąd ważna jest świadomość, że dziecko powinno poznawać nie tylko te treści, które są dla niego w danym momencie atrakcyjne, tak jak zostało to wskazane przez badanych rodziców. 


\section{BIBLIOGRAFIA}

\section{LITERATURA}

Gajdzica A. (2006). Reforma oświaty a praktyka edukacji wczesnoszkolnej. Katowice: Wydawnictwo Uniwersytetu Śląskiego.

Gajdzica, A. (2013a). Balast czy narzędzie władzy - opinie nauczycieli o politykach i polityce oświatowej MEN. Teraźniejszość - Człowiek - Edukacja, (2), 127-138.

Gajdzica, A. (2013b). Portret zbiorowy nauczycieli aktywnych - między zaangażowaniem a oporem wobec zmian. Torun-Cieszyn: Wydział Etnologii i Nauk o Edukacji Uniwersytetu Śląskiego, Wydawnictwo Adam Marszałek.

Kobus, I. (2014). Edukacja domowa. Dyrektor Szkoty, (8), 48-50.

Kuźmińska-Sołśnia, B. (2018). Nauka programowania/kodowania w edukacji najmłodszych. Dydaktyka Informatyki, 13, 121-128. DOI: https://doi.org/10.15584/di.2018.13.15

Kwieciński, Z. (2012). Pedagogie postu. Preteksty, konteksty, podteksty. Kraków: Oficyna Wydawnicza Impuls.

Marszałek, A. (2018). Jak rozpocząć? Formalności i kwestie prawne. Magazyn Kreatywnej Edukacji Kreda, (1), 32-33.

Sawiński, J.P. (2008). Co z edukacją domową w XXI wieku? Nowa Szkoła, (10), 26-29.

Szafrańska, A., Seberová, A., Kasáčová, B., Babiaková, S. (2017). Selected Problems of Teachers' Functioning in Central and Eastern Europe: A Polish-Czech-Slovak Study. Ostrava: Faculty of Education, Ostrava University.

Szafrańska, A., Pawlak, J. (2020). W poszukiwaniu lepszych możliwości kształcenia dla własnego dziecka. Edukacja domowa z perspektywy rodziców. Przegląd Pedagogiczny, (1), 203-218.

Śliwerski, B. (2009). Problemy wspótczesnej edukacji. Dekonstrukcja polityki oświatowej III RP. Warszawa: Wydawnictwa Akademickie i Profesjonalne.

Śliwerski, B. (2012). Szkoła na wirażu zmian politycznych. Bez cenzury. Kraków: Oficyna Wydawnicza Impuls.

Śliwerski, B. (2015). Edukacja (w) polityce. Polityka (w) edukacji. Kraków: Oficyna Wydawnicza Impuls. Zielińska, A. (2009). Aspekty prawne nauczania domowego. W: M. i P. Zakrzewscy (red.), Edukacja domowa w Polsce. Teoria i praktyka (s. 475-490). Warszawa: Oficyna Wydawniczo-Poligraficzna „Adam”.

\section{NETOGRAFIA}

Dzieciątko, J. i M. (2017). Debata: Edukacja domowa wobec zmian ustawowych. Jedna tezapięć perspektyw. Pobrane z: http://edukacjadomowa.pl/debata-edukacja-domowa-wobec-zmian-ustawowych-jedna-teza-piec-perspektyw (dostęp: 10.01.2021).

www1: https://szkolamontessori.com.pl/edukacja-domowa-rekrutacja (dostęp: 7.08.2019).

www2: www.facebook.com/groups/121898927825626/about (dostęp: 7.08.2019).

www3: www.facebook.com/groups/895115517301932/about (dostęp: 7.08.2019).

www4: www.juniorowo.pl/edukacja-domowa-lupa (dostęp: 7.08.2019).

\section{AKTY PRAWNE}

Ustawa z dnia 7 września 1991 r. o systemie oświaty (Dz.U. 1991, nr 95, poz. 425).

Ustawa z dnia 14 grudnia 2016 r. - Prawo oświatowe (Dz.U. 2017, poz. 59). 


\begin{abstract}
With growing frequency, school faces critical assessment and the need increases for possibilities of alternative education for children and youth. What seems to be compliant with this is more and more popular home education (home schooling) - in Poland there is no school duty but educational duty. The conducted research indicate that parents who undertake home education resign from school due to both the negative opinion about it and their own experience. These two factors make parents want to protect their children from negative influence of school. This article presents the analyses of the obtained research results concerning parental declarations on the required competences, qualifications and knowledge useful in home schooling, as well as the respondents' organization of the educational process itself in the system of home education.
\end{abstract}

Keywords: home education; parents; organization of the educational process 